\title{
Effects of acute cold stress on energy metabolism, skeletal muscle oxygenation, and exercise performance
}

\author{
Hun-Young Park ${ }^{1,2}$, Won-Sang Jung ${ }^{1}$, Hyejung Hwang ${ }^{1}$, Sung-Woo Kim ${ }^{1}$, Kyunghwa Jung ${ }^{3}$, \\ Yeram Park ${ }^{3}$, Deunsol Hwang ${ }^{3}$, Sunghwan Kyun ${ }^{3}$, Jongbeom Seo ${ }^{2}$, Yujin Ha², Inkwon Jang ${ }^{2}$, \\ Jisu Kim ${ }^{1,2}$, \& Kiwon Lim ${ }^{1,2,3 *}$ \\ ${ }^{1}$ Physical Activity and Performance Institute, Konkuk University, ${ }^{2}$ Department of Sports Medicine and Science, Graduated School, \\ Konkuk University, ${ }^{3}$ Department of Physical Education, Konkuk University
}

[Purpose] This study aimed to investigate the effects of acute cold stress $\left(10^{\circ} \mathrm{C}, 0^{\circ} \mathrm{C}\right)$ compared with ordinary temperature $\left(20^{\circ} \mathrm{C}\right)$ on exercise performance and physiological response at rest and during exercise. [Methods] A total of 10 healthy men $(21.55 \pm 2.16)$ were selected. In each environmental condition $\left(20^{\circ} \mathrm{C}, 10^{\circ} \mathrm{C}, 0^{\circ} \mathrm{C}\right)$, the three testing order was randomly selected at crossover, and there was a week interval between the graded exercise test (GXT). On the testing day, they remained resting for 30 min in each environmental condition. Dependent variables (body temperature, energy metabolism parameters, skeletal muscle oxygenation profiles, and exercise performance parameters) were measured at rest and during GXT. [Results] In body temperature, at each environmental condition, there was a significant decrease $(\mathrm{p}<.05)$ at $10^{\circ} \mathrm{C}$ and $0{ }^{\circ} \mathrm{C}$ compared with $20^{\circ} \mathrm{C}$ after exercise, and in the difference depending on the environment at rest. After exercise, the body temperature significantly decreased $(p<.05)$ in proportion to the decrease in temperature. There was no difference in heart rate and blood lactate level in energy metabolism, and the respiratory exchange ratio was significantly higher $(p<.05)$ at $0^{\circ} \mathrm{C}$ than $20^{\circ} \mathrm{C}$. Minute ventilation $(\mathrm{VE})$, oxygen uptake $\left(\mathrm{VO}_{2}\right)$, and carbon dioxide excretion $\left(\mathrm{VCO}_{2}\right)$ were significantly lower $(\mathrm{p}<.05)$ at $0^{\circ} \mathrm{C}$ than $20^{\circ} \mathrm{C}$ and $10^{\circ} \mathrm{C}$ at various exercise load. All skeletal muscle oxygenation profiles did not show significant changes at rest and during exercise. In exercise performance, maximal oxygen uptake was significantly lower $(\mathrm{p}<.05)$ at $0^{\circ} \mathrm{C}$ than $20^{\circ} \mathrm{C}$, and exercise time to exhaustion was also significantly lower $(\mathrm{p}<.05)$ at $0^{\circ} \mathrm{C}$ than $20^{\circ} \mathrm{C}$ and $10^{\circ} \mathrm{C}$. [Conclusion] Acute cold stress induces deterioration of exercise performance via a decreased body temperature and an increase in $\mathrm{VE}, \mathrm{VO}_{2}$, and $\mathrm{VCO}_{2}$ during the same exercise load. In addition it was confirmed that this phenomenon was more prominent at $0^{\circ} \mathrm{C}$ than at $10^{\circ} \mathrm{C}$ when compared to $20^{\circ} \mathrm{C}$.

Key words: cold stress, energy metabolism, skeletal muscle oxygenation, exercise performance

\section{서 론}

논문 투고일 : 2020. 08. 25.

논문 수정일 : 2020. 09. 26.

게재 확정일 : 2020. 10. 04.

* 교신저자 : 임기원 (exercise@konkuk.ac.kr).

* 이 논문은 2020년도 건국대학교 우수연구인력 양성사업 지원에 의한 논문임.
스포츠 현장에서 선수들은 종목 특성에 따라 저온환경 에서 경기를 수행해야 하는 다양한 상황에 직면하게 된 다. 저온환경의 급성노출은 운동을 수행함에 있어 힘, 속 도, 파워 등을 저하시키고 다양한 생리적 반응에 영향을 
미쳐 경기력을 제한하게 된다(Castellani \& Young, 2016; Son'kin et al., 2014; Wakabayashi et al., 2015). 특히 저온환경은 골격근의 저체온 현상 (hypothermic skeletal muscle)을 유발하게 되며, 이는 골격근으로의 신경전도속도(nerve conduction velocity)를 둔화시키고 근형질세망(sarcoplasmic reticulum, SR)에서의 칼슘이온의 방출과 흡수 능력 저 하 및 아데노신삼인산(adenosine triphosphate, ATP) 이용률 저하를 가져와 근육 수축 속도 감소를 가져오는 것으로 보고되고 있다(De Jong et al., 1966; Edwards et al., 1972; Herve et al., 1992; He et al., 2000; Wakabayashi et al., 2015). 결과적으로 전술한 바와 같은 기전에 의해 등척성 및 등장성 수축과 같은 기능적 측면뿐만 아니라 실질적인 운동수행능력과 경기력을 감 소시키는 것으로 보고되고 있다(Drinkwater, 2008; Drinkwater \& Behm, 2007; Oksa, 2002; Racinais \& Oksa, 2010).

이외에도 저온환경의 급성노출은 대사 및 심혈관계에 있어서 다양한 생리적 반응을 나타내게 된다. 저온환경에 의 노출은 스트레스로 작용하여 교감신경계의 활성도를 증가시키고 부교감신경계의 활성도를 감소시키게 되며, 이에 생리적으로 말초혈관의 저항을 증가시켜 심박수 (heart rate, HR)와 혈압(blood pressure, $\mathrm{BP}$ )을 높이 게 된다(Gonzalez-Camarena et al., 2000; Manou-Stathopoulou et al., 2015; Nybo \& Nielsen, 2001). 또한 대사적으로 냉각된 근육에서 혈류제한으로 인해 산소공급이 저하되고 근 글리코겐(muscle glycogen)의 파괴와 해당작용(glycolysis) 촉진 현상이 나타나며, 이로 인해 혈중젖산농도가 증가되는 것으로 보 고되고 있다(Thorsson et al., 1985; Pilcher et al., 2002; Gregson et al., 2011). 저온환경에서의 운동은 전술한 생리적 기전에 의해 근육으로의 산소전달 및 이용 능력이 제한되어 무산소성 역치(anaerobic threshold) 와 최대산소섭취량(maximal oxygen uptake, $\mathrm{VO}_{2} \mathrm{max}$ ) 이 감소하며, 최대하 운동 시 에너지 대사 효율이 저하되 게 된다(Stocks et al., 2004).

이렇듯 저온환경에서의 급성 노출은 안정시와 운동 중 다양한 생리적 변화를 유도함으로써 운동수행능력 및 경 기력을 감소시키는 기전을 나타낸다는 것을 확인할 수 있
다. 그러나 저온환경과 운동수행능력 간의 관계를 검토한 선행연구들을 살펴보면, 대부분의 연구가 $20-22^{\circ} \mathrm{C}$ 정도 의 상온과 $10^{\circ} \mathrm{C}$ 전후의 약간의 저온 정도의 환경조건만 을 검토하고 있으며, 측정하고 있는 변인 또한 심박수와 호흡가스분석을 통한 에너지 대사 관련 변인에만 국한되 어 있다(Lee \& Jeon, 2013; No \& Kwak, 2016; Falk et al., 1994). 이에 대해서 자세히 살펴보면, Falk et al. (1994)은 저온환경에의 급성 노출에 의한 연령에 따 른 체온과 심폐기능의 차이가 단순한 연령 때문인지 연령 증가에 따른 $\mathrm{VO}_{2} \max$ 감소에 의한 영향인지를 검토하였 으며, Lee \& Jeon(2013)은 외부환경온도가 운동수행능 력에 미치는 영향을 알아보기 위해 저온 $\left(5 \pm 0.5^{\circ} \mathrm{C}\right)$ 과 상 온 $\left(20 \pm 0.5^{\circ} \mathrm{C}\right)$ 에서 $\mathrm{VO}_{2} \max 60 \%$ 에 해당되는 운동강도 로 30 분간 운동 중 산소섭취량(oxygen uptake, $\mathrm{VO}_{2}$ ), 최대심박수(maximal heart rate, HRmax), 호흡교환율 (respiratory exchange ratio, RER), 혈중젖산농도에 있어서 차이가 있음을 보고하였다. No \& $\operatorname{Kwak}(2016)$ 은 9명의 측구선수를 대상으로 cross-over study를 바탕 으로 동일한 습도조건 $(60 \pm 10 \%)$ 에서 저온인 $10 \pm 1^{\circ} \mathrm{C}$ 와 상온인 $22 \pm 1^{\circ} \mathrm{C}$ 에서 운동수행능력과 생리적 반응 변화를 검토한 결과, 최대하 운동 중 상온에서 저온보다 유의하 게 더 낮은 $\mathrm{HR}, \mathrm{VO}_{2}$, 분당환기량(minute ventilation, $\mathrm{VE}$, 혈중젖산농도를 나타냈으며, 운동지속시간은 더 높 은 기록을 나타냈다고 보고하였다. 이와 같이 대부분의 선행연구들은 저온환경에의 급성 노출에 의한 운동수행 능력의 감소를 호흡가스를 통한 에너지 대사관련 변인 및 심혈관 반응에서만 단순하게 검토하고 있는 실정이다.

이러한 추운환경에서 급성 노출에 따른 생리적 변화와 운동수행능력의 관계를 보다 정확하게 규명하기 위해서 는 선행연구에서 검토한 다양한 저온환경 조건에서 호흡 가스를 통한 에너지 대사 관련 변인 및 심혈관 반응의 검 토뿐만 아니라 운동수행능력에 중요한 영향을 미치는 근 조직에서의 국소적인 산소이용능력을 검토할 수 있는 근 적외선 분광법(near infrared spectroscopy, NIRS)을 활용하는 것이 매우 중요하다(Binzoni et al., 2002; Hom et al., 2004; Yanagisawa et al., 2007).이러한 $\mathrm{NIRS}$ 의 활용은 저온환경에 의한 운동수행능력 감소의 원인을 호흡보다 심도 있게 해석할 수 있는 근거를 마련 할 수 있는 것으로 생각하며, 우리는 저온환경에의 급성 
노출에 의한 골격근 산소화 농도의 변화가 운동수행능력 에 영향을 미칠 것이라고 판단된다.

따라서, 본 연구에서는 저온환경에의 급성 노출이 대 사 및 호흡 순환계뿐만 아니라 NIRS를 이용해 검토할 수 있는 골격근 산소화 농도의 반응 변화를 통해 운동수행능 력 및 경기력에 영향을 미칠 것으로 가설을 세워서 연구 를 수행하였다. 가설을 바탕으로 한 본 연구의 목적은 20 대의 건강한 남성을 대상으로 상온환경 $\left(20^{\circ} \mathrm{C}\right)$ 과 비교하 여 다양한 저온환경 $\left(10^{\circ} \mathrm{C}, 0^{\circ} \mathrm{C}\right)$ 에서의 급성노출이 운동 수행능력과 운동 중 생리적 반응에 미치는 영향을 호흡가 스를 통한 에너지 대사와 NIRS를 활용한 골격근 산소화 농도를 통해 검토하였다.

\section{연구방법}

\section{연구대상}

본 연구의 대상자는 최근 1 년 동안 정형외과적-내과적 질환 경험이 없는 건강한 20 대 남성 10 명을 선별하였으며, 선정된 10 명의 연구대상자는 상온 $\left(20^{\circ} \mathrm{C}\right)$ 및 다양한 저온 환경 조건 $\left(10^{\circ} \mathrm{C}, 0^{\circ} \mathrm{C}\right)$ 에서 총 3 번의 최대운동부하검사 (graded exercise test, GXT)를 실시하였다. 연구 시작 전 모든 대상자에게 연구의 목적과 절차를 충분히 설명하였으 며, 이를 이해하고 자발적으로 참여하고자 하는 자로부터 건국대학교 임상시험 심사위원회(institutional review board; IRB)의 승인여부(7001355-201805-HR-241)를 알린 후 모든 대상자에게 연구의 목적과 절차를 충분히 설명하였으며, 이를 이해하고 자발적으로 참여하고자 하 는 자로부터 동의서를 받은 후 연구에 참여하도록 하였 다. 연구대상자들의 신체적인 특성은 〈Table 1)과 같다.

\section{연구설계}

본 연구의 목적을 달성하기 위해서 연구대상자가 실험 실에 도착하면, 신체구성을 먼저 측정한 후 실험진행을 실시하고자 하는 환경조건 $\left(20^{\circ} \mathrm{C}, 10^{\circ} \mathrm{C}, 0^{\circ} \mathrm{C}\right)$ 에서 각각 30 분간 안정 상태를 유지한 후 종속변인(체온, 호흡가스 를 통한 에너지 대사, 골격근 산소화 농도, 운동수행능
Table 1. Characteristic subjects (Mean \pm SD)

\begin{tabular}{cc}
\hline \hline Variables & Male $(\mathrm{n}=10)$ \\
\hline Age $($ years $)$ & $21.55 \pm 2.16$ \\
\hline Height $(\mathrm{cm})$ & $178.51 \pm 5.62$ \\
\hline Weight $(\mathrm{kg})$ & $70.65 \pm 4.21$ \\
\hline Body mass index $\left(\mathrm{kg} / \mathrm{m}^{2}\right)$ & $22.19 \pm 1.31$ \\
\hline Free fat mass $(\mathrm{kg})$ & $62.13 \pm 4.96$ \\
\hline Body fat mass $(\mathrm{kg})$ & $8.52 \pm 2.53$ \\
\hline Percentage body fat $(\%)$ & $12.10 \pm 3.64$ \\
\hline \hline
\end{tabular}

력)에 대한 안정시 측정을 수행하였다. 그 후 대상자가 운 동을 수행할 준비가 되면 모나크 자전거 에르고미터 (Monark ergomedic 828E, Monark, Varberg, Sweden)를 이용하여 각 환경조건에서 GXT를 실시하였 다. 운동 중 데이터를 획득하기 위해 운동 중 10 초 단위 로 대상자의 에너지 대사 및 골격근 산소화 농도 관련 변 인을 측정하여 각 구간 2 분마다의 평균값을 측정값으로 산출하였다. 혈중젖산농도는 GXT 수행하는 동안 매분 측정하여 동일하게 2 분마다 평균값을 측정값으로 산출하 였으며, 체온은 안정시와 운동직후에 측정을 실시하였 다. GXT 수행 후 각 운동강도에서의 에너지 대사 및 골격 근 산소화 농도 관련 변인에 대한 데이터 처리는 모든 대

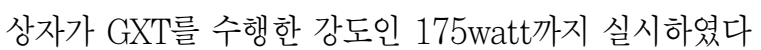
〈Figure 1〉. 그 이후의 데이터는 운동수행능력을 측정 및 평가하기 위한 목적으로만 사용하였다.

본 연구를 수행하는 동안 각 환경조건에서의 적응 효 과를 제거하기 위해서 각 환경조건에서의 GXT 검사 간 일주일 간격을 두었으며, 환경조건에 대한 순서를 불규 칙하게 무작위로 선정(random sampling)하였다.



Fig. 1. Flow chart for the end of graded exercise test in all subjects. 


\section{측정 항목 및 방법}

본 연구에서는 다양한 종속변인을 안정 시 및 최대운 동부하검사를 실시하는 동안 측정하였으며, 자세한 측정 항목 및 방법은 다음과 같다.

\section{1) 다양한 저온환경의 조성}

상온 및 저온에 해당되는 환경조성을 위해 (주나라콘트 롤에서 개발한 16 인용 $(9 \mathrm{~m} \times 7 \mathrm{~m} \times 3 \mathrm{~m})$ 환경제어챔버 (NCTC-1, Nara Control, Seoul, Korea)를 활용하였으 며, 본 연구를 위해서 다양한 환경조건 $\left(20 \pm 1^{\circ} \mathrm{C}, 10 \pm 1^{\circ} \mathrm{C}\right.$, $0 \pm 1^{\circ} \mathrm{C}$ )을 조성하였다〈Figure 2$\rangle$. 습도조건은 모든 환경 에서 $50 \pm 5 \%$ 로 동일하게 유지하였다.

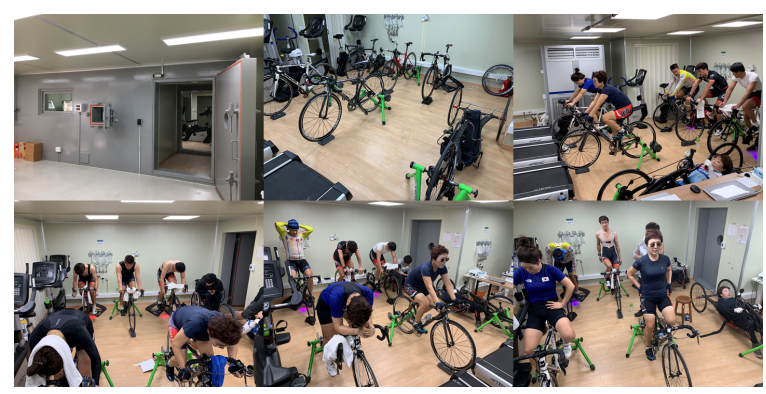

Fig. 2. Environmental control chamber.

\section{2) 신체구성 측정}

생체전기저항분석기(bioelectrical impedance analysis; Inbody 770, Seoul, Korea)를 이용하여 체중, 제지방량, 체지방량, 체지방률을 측정하였다. 측정 전 각 대상자는 음식물을 섭취하지 않은 상태로 4시간 이상 금식한 후, 생체전기저항분석기 전극판 위에 맨발로 바르게 올라서 게 한 후 전극을 양손으로 각각 잡고 엄지손가락으로 전 극 스위치를 가볍게 누르도록 한 상태에서 좌·우 다리와 손가락의 피부전기저항 8점을 측정하여 체중, 제지방량, 체지방량은 $\mathrm{kg}$ 단위로, 체지방률은 \%단위로 측정하였다.

\section{3) 체온 측정}

체온은 IRT-6510 체온계(Brown Healthcare, Seoul, Korea)를 이용하여 안정시와 운동 직후 고막 측 정법을 이용하여 측정하였다. 측정은 2 회 수행하였고, 평 균값을 측정값으로 활용하였다.

\section{4) 최대운동부하검사}

최대운동부하검사를 위해 모나크 자전거(Monark ergomedic 828E, Monark, Varberg, Sweden)를 이용 하였으며, 다양한 환경조건에서 수행하는 것을 고려하여 최초 $300 \mathrm{~kg} \cdot \mathrm{m} \cdot \mathrm{min}^{-1}$ (50 watt)에서 시작하여 2 분마다 운동 부하를 $150 \mathrm{~kg} \cdot \mathrm{m} \cdot \mathrm{min}^{-1}$ (25 watt)씩 증가시켜 수행 하였다. 페달링 속도는 $60 \mathrm{rpm}$ 으로 설정하였다. 모든 검 사는 대상자가 마스크를 착용한 후 모든 호흡가스 지표들 이 안정되었을 때 측정을 시작하여 모든 대상자들에게 있 어서 최대치의 $\mathrm{VO}_{2} \max$ 가 나타날 수 있도록 많은 독려를 하였다. 검사 종료는 아래 항목 중 최소 3 가지 이상이 충 족되었을 때 탈진상태에 도달한 것으로 판정하여 운동을 종료하였다. (1) $\mathrm{HR}$ 이 운동강도에 비례적으로 증가하지 않을 때, (2) 운동강도가 증가하더라도 $\mathrm{VO}_{2}$ 가 증가하지 않을 때, (3) RER이 1.10 이상일 때, (4) 보그 척도(Borg scale)이 17 이상일 때, (5) 예측 $\mathrm{HRmax}$ 가 $90 \%$ 이상을 초과하였을 때에 해당된다.

\section{5) 에너지 대사 관련 변인 측정}

자동호흡 대사분석기인 K5(Sensormedics, Rome, Italy), 모나크 자전거(Monark ergomedic $828 \mathrm{E}$, Monark, Varberg, Sweden), 심박수 측정기(V800, Polar, Helsinki, Finland)를 이용하여 안정시 및 최대 운동부하검사를 수행하는 동안의 호흡가스를 통한 에너 지 대사 관련 변인을 측정하였다. 에너지 대사 관련 변인 으로 $\mathrm{HR}$, 분당환기량(minute ventilation, $\mathrm{VE}$ ), $\mathrm{VO}_{2}$, 이산화탄소배출량(carbon dioxide excretion, $\mathrm{VCO}_{2}$ ), $\mathrm{RER}$, 혈중젖산농도를 측정하였다.

혈중젖산농도는 안정시 및 최대운동부하검사를 진행 하는 동안 매분마다 손 끝 모세혈관에서 $80 \mu \mathrm{l}$ 의 혈액을 채취하여 Lactate pro2 젖산분석기(Arkray, Kyoto, Japan)를 이용하여 분석하였다.

\section{6) 골격근 산소화 농도 측정}

골격근 산소화 농도의 측정은 근적외선 분광측정장치 (Near Infrared Spectrocopy: NIRS, Astem, Mizonokuchi, Japan)를 이용하여 우측 대퇴 외측광근에서 산화된 헤모 글로빈(oxygenated hemoglobin: Oxy_Hb), 탈산화된 헤모글로빈(deoxygenated hemoglobin: Deoxy_Hb), 
총 헤모글로빈(total hemoglobin: Total_Hb) 및 조직 산소포화도(tissue oxygen saturation: $\mathrm{S}_{\mathrm{t}} \mathrm{O}_{2}$ ) 를 측정하 였다. 측정을 위해 NIRS probe를 무릎에서 10- $15 \mathrm{~cm}$ 위 쪽의 대퇴 외측광근 부위에 부착한 후 안정시부터 운동을 종료할 때까지 10 초마다 측정된 데이터를 기록하여 2 분 의 평균값으로 사용하였다.

\section{7) 운동수행능력 측정}

상온과 다양한 저온환경과의 운동수행능력 차이를 평 가하기 위해서 GXT 수행에 따른 $\mathrm{VO}_{2} \max$, 최대운동부 하(maximal exercise load), 운동지속시간(exercise time to exhaustion)를 측정하였다.

\section{통계 처리}

수집된 데이터의 자료분석을 위해 $\mathrm{SPSS} \mathrm{PC}^{+}$for Windows (version 25.0) 통계 프로그램을 이용하였으 며, 모수 통계분석을 위해 데이터가 정규분표에 해당되는 지를 Shapiro-Wilks 테스트를 통해 검증하였으며, 모든 종속변인의 기술통계량을 제시하기 위해서 평균과 표준 편차를 각각 산출하였다. 각 환경조건과 운동시간에 따른 상호작용효과를 검증하기 위해 반복이원분산분석을 실 시하였으며, 유의한 상호작용효과가 나타나는 경우, 본 연구의 목적인 각 시점에서의 집단 간 차이를 검증하기 위해서 반복일원분산분석을 실시하였다. 사후분석은 Bonferoni를 활용하였다. 모든 추리통계에서의 통계적 유의수준은 $\alpha=.05$ 로 설정하였다.

\section{연구결과}

\section{체온의 변화}

상온과 두 가지의 저온환경에서 안정시와 GXT 직후 체온의 변화는 〈Table 2 〉 및 〈Figure 3〉와 같다. 환경과 측정시기 간에 유의한 상호작용효과가 나타났다( $\mathrm{p}<.05)$. 사후분석 결과 각 기온 조건에서 운동 직후 $10^{\circ} \mathrm{C}$ 저온과 $0^{\circ} \mathrm{C}$ 저온에서 체온의 유의한 감소가 나타났으며 $(\mathrm{p}<.05)$, 안정시와 운동 직후 각각에서의 기온에 따른 차이에서는
양쪽 모두에서 기온이 감소함에 따라 그에 비례하여 체온 이 유의하게 감소하였다(p〈.05).

Table 2. Change of body temperature at rest and after exercise end (mean $\pm \mathrm{SD})$

\begin{tabular}{ccc}
\hline \hline Environment & Rest & Exercise_end \\
\hline $20^{\circ} \mathrm{C}$ & $36.5 \pm 0.4$ & $36.3 \pm 0.5$ \\
\hline $10^{\circ} \mathrm{C}$ & $36.0 \pm 0.5^{\dagger}$ & $35.1 \pm 0.7^{\dagger}$ \\
\hline $0^{\circ} \mathrm{C}$ & $35.3 \pm 0.6^{\#, \ddagger}$ & $34.4 \pm 0.5^{\#,+}$ \\
\hline \hline
\end{tabular}

Note. $\dagger$ : significant difference between $20^{\circ} \mathrm{C}$ and $10^{\circ} \mathrm{C}$ at each time, $\uparrow$ : significant difference between $20^{\circ} \mathrm{C}$ and $0^{\circ} \mathrm{C}$ at each time, \#: significant difference between $10^{\circ} \mathrm{C}$ and $0^{\circ} \mathrm{C}$ at each time.

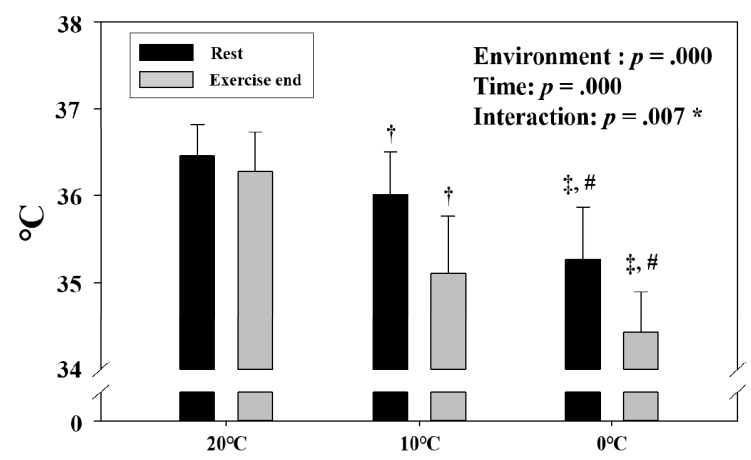

Fig. 3. Change of body temperature at rest and after exercise end (Mean $\pm \mathrm{SD}$ ).

*: signficant interaction, $\dagger$ : significant difference between $20^{\circ} \mathrm{C}$ and $10{ }^{\circ} \mathrm{C}$ at each time, $\ddagger$ : significant difference between $20^{\circ} \mathrm{C}$ and $0{ }^{\circ} \mathrm{C}$ at each time, \#: significant difference between $10{ }^{\circ} \mathrm{C}$ and $0{ }^{\circ} \mathrm{C}$ at each time.

\section{에너지 대사 관련 변인의 변화}

상온과 두 가지 저온환경에서의 안정시와 GXT 직후 에너지 대사 관련 변인에 해당되는 $\mathrm{HR}, \mathrm{VE}, \mathrm{VO}_{2}$, $\mathrm{VCO}_{2}, \quad \mathrm{RER}$, 혈중젖산농도의 변화는〈Table 3〉 및 〈Figure 4〉에서 보는 바와 같으며, 혈중젖산농도를 제외 한 모든 변인인 $\mathrm{HR}, \mathrm{VE}, \mathrm{VO}_{2}, \mathrm{VCO}_{2}, \mathrm{RER}$ 에서 유의한 상호작용효과가 나타났다 $(\mathrm{p}<.05)$.

이에 대한 각 시점에서 기온에 따른 차이에 대한 사후 분석결과, $\mathrm{HR}$ 에서는 어떠한 차이도 나타나지 않았으며, $\mathrm{RER}$ 은 안정시에 $0^{\circ} \mathrm{C}$ 저온에서 $20^{\circ} \mathrm{C}$ 상온보다 유의하게 높은 값을 보였다( $\mathrm{p}<.05)$. VE는 $50 \mathrm{watt}$ 에서 $0^{\circ} \mathrm{C}$ 저온의 경우 $20^{\circ} \mathrm{C}$ 상온 및 $10^{\circ} \mathrm{C}$ 저온 보다 유의하게 높은 값을 
Table 3. Change of energy metabolism parameters at rest and during exercise (descriptive statistics; Mean \pm SD)

\begin{tabular}{|c|c|c|c|c|c|c|c|c|}
\hline Variables & Environment & Rest & $50 \mathrm{~W}$ & $75 \mathrm{~W}$ & $100 \mathrm{~W}$ & $125 \mathrm{~W}$ & $150 \mathrm{~W}$ & $175 \mathrm{~W}$ \\
\hline \multirow{3}{*}{$\begin{array}{l}\mathrm{HR} \\
\text { (bpm) }\end{array}$} & $20^{\circ} \mathrm{C}$ & $65.5 \pm 6.5$ & $84.0 \pm 9.6$ & $94.7 \pm 8.5$ & $106.9 \pm 9.8$ & $122.4 \pm 13.1$ & $139.0 \pm 15.2$ & $154.8 \pm 15.6$ \\
\hline & $10^{\circ} \mathrm{C}$ & $63.8 \pm 7.0$ & $85.5 \pm 8.8$ & $95.0 \pm 9.5$ & $106.8 \pm 11.1$ & $121.6 \pm 14.4$ & $138.0 \pm 17.4$ & $154.5 \pm 16.8$ \\
\hline & $0^{\circ} \mathrm{C}$ & $67.3 \pm 7.1$ & $88.5 \pm 12.5$ & $97.8 \pm 12.2$ & $106.9 \pm 14.1$ & $119.1 \pm 14.6$ & $134.9 \pm 16.1$ & $149.9 \pm 16.9$ \\
\hline \multirow{3}{*}{$\begin{array}{c}\mathrm{VE} \\
(\mathrm{L} / \mathrm{min})\end{array}$} & $20^{\circ} \mathrm{C}$ & $11.3 \pm 3.7$ & $16.9 \pm 3.6$ & $28.5 \pm 5.7$ & $36.9 \pm 5.3$ & $45.4 \pm 5.1$ & $57.7 \pm 7.2$ & $74.2 \pm 12.3$ \\
\hline & $10^{\circ} \mathrm{C}$ & $10.8 \pm 2.5$ & $18.6 \pm 5.1$ & $27.3 \pm 5.3$ & $35.3 \pm 5.6$ & $45.5 \pm 7.2$ & $56.1 \pm 8.2$ & $69.6 \pm 12.0$ \\
\hline & $0^{\circ} \mathrm{C}$ & $13.2 \pm 2.3$ & $22.5 \pm 4.6^{\#,+}$ & $32.5 \pm 5.3 \#$ & $40.6 \pm 4.8^{\#}$ & $48.2 \pm 4.4$ & $58.4 \pm 6.1$ & $72.9 \pm 12.8$ \\
\hline \multirow{3}{*}{$\begin{array}{c}\mathrm{VO}_{2} \\
(\mathrm{~mL} / \mathrm{min})\end{array}$} & $20^{\circ} \mathrm{C}$ & $358.8 \pm 102.2$ & $588.6 \pm 123.0$ & $1235.6 \pm 268.7$ & $1521.4 \pm 204.3$ & $1767.4 \pm 159.9$ & $2098.6 \pm 199.8$ & $2453.1 \pm 266.0$ \\
\hline & $10^{\circ} \mathrm{C}$ & $358.6 \pm 48.4$ & $659.0 \pm 197.2$ & $1209.7 \pm 179.7$ & $1509.7 \pm 174.6$ & $1773.4 \pm 165.7$ & $2031.5 \pm 162.6$ & $2345.5 \pm 204.0$ \\
\hline & $0^{\circ} \mathrm{C}$ & $425.2 \pm 41.6$ & $818.8 \pm 185.8^{\ddagger}$ & $1408.9 \pm 192.0 \#, \dagger$ & $1702.9 \pm 184.3^{\#, \ddagger}$ & $1907.7 \pm 176.3$ & $2150.1 \pm 158.8$ & $2371.4 \pm 123.2$ \\
\hline \multirow{3}{*}{$\begin{array}{c}\mathrm{VCO}_{2} \\
(\mathrm{~mL} / \mathrm{min})\end{array}$} & $20^{\circ} \mathrm{C}$ & $281.3 \pm 89.5$ & $442.8 \pm 103.5$ & $935.8 \pm 194.6$ & $1306.4 \pm 188.9$ & $1659.4 \pm 177.9$ & $2102.6 \pm 232.2$ & $2576.6 \pm 337.7$ \\
\hline & $10^{\circ} \mathrm{C}$ & $299.0 \pm 46.5$ & $524.8 \pm 140.6$ & $913.5 \pm 150.7$ & $1281.7 \pm 162.2$ & $1661.3 \pm 176.0$ & $2028.0 \pm 178.6$ & $2465.1 \pm 261.5$ \\
\hline & $0^{\circ} \mathrm{C}$ & $377.3 \pm 51.2 \#,+$ & $657.8 \pm 136.2^{\#, \ddagger}$ & $1103.8 \pm 178.6 \#, \$$ & $1468.3 \pm 161.7^{\#, \$}$ & $1795.8 \pm 151.6 \#, \dagger$ & $2178.9 \pm 149.8$ & $2571.3 \pm 176.9$ \\
\hline \multirow{3}{*}{ RER } & $20^{\circ} \mathrm{C}$ & $0.78 \pm 0.05$ & $0.76 \pm 0.11$ & $0.76 \pm 0.08$ & $0.86 \pm 0.06$ & $0.94 \pm 0.05$ & $1.00 \pm 0.04$ & $1.05 \pm 0.05$ \\
\hline & $10^{\circ} \mathrm{C}$ & $0.83 \pm 0.05$ & $0.81 \pm 0.06$ & $0.75 \pm 0.03$ & $0.85 \pm 0.04$ & $0.94 \pm 0.06$ & $1.00 \pm 0.05$ & $1.05 \pm 0.06$ \\
\hline & $0^{\circ} \mathrm{C}$ & $0.89 \pm 0.07 \ddagger$ & $0.82 \pm 0.09$ & $0.78 \pm 0.04$ & $0.86 \pm 0.03$ & $0.94 \pm 0.03$ & $1.01 \pm 0.04$ & $1.08 \pm 0.05$ \\
\hline \multirow{3}{*}{$\begin{array}{c}\text { Blood } \\
\text { lactate } \\
(\mathrm{mmol} / \mathrm{L})\end{array}$} & $20^{\circ} \mathrm{C}$ & $1.14 \pm 0.14$ & $1.27 \pm 0.17$ & $1.49 \pm 0.24$ & $1.85 \pm 0.32$ & $2.36 \pm 0.59$ & $3.35 \pm 0.90$ & $4.77 \pm 1.38$ \\
\hline & $10^{\circ} \mathrm{C}$ & $1.15 \pm 0.24$ & $1.29 \pm 0.24$ & $1.51 \pm 0.28$ & $1.72 \pm 0.45$ & $2.22 \pm 0.72$ & $3.07 \pm 1.05$ & $4.46 \pm 1.71$ \\
\hline & $0^{\circ} \mathrm{C}$ & $1.14 \pm 0.18$ & $1.24 \pm 0.20$ & $1.55 \pm 0.34$ & $2.00 \pm 0.52$ & $2.54 \pm 0.88$ & $3.55 \pm 1.09$ & $4.71 \pm 1.47$ \\
\hline
\end{tabular}

†: significant difference between $20^{\circ} \mathrm{C}$ and $0^{\circ} \mathrm{C}$ at each exercise load, \#: significant difference between $10^{\circ} \mathrm{C}$ and $0^{\circ} \mathrm{C}$ at each exercise load. HR: heart rate, VE: minute ventilation, $\mathrm{VO}_{2}$ : oxygen uptake, $\mathrm{VCO}_{2}$ : cardon dioxide excretion, $\mathrm{RER}$ : respiratory exchange ratio.

Table 4. Change of skeletal muscle oxygen profiles at rest and during exercise (descriptive statistics; Mean \pm SD)

\begin{tabular}{|c|c|c|c|c|c|c|c|c|}
\hline Variables & Environment & Rest & $50 \mathrm{~W}$ & $75 \mathrm{~W}$ & $100 \mathrm{~W}$ & $125 \mathrm{~W}$ & $150 \mathrm{~W}$ & $175 \mathrm{~W}$ \\
\hline \multirow{3}{*}{$\begin{array}{c}\mathrm{Oxy} \mathrm{Hb} \\
(\mathrm{mM})\end{array}$} & $20^{\circ} \mathrm{C}$ & $0.05 \pm 0.01$ & $0.05 \pm 0.01$ & $0.04 \pm 0.01$ & $0.04 \pm 0.01$ & $0.03 \pm 0.01$ & $0.02 \pm 0.01$ & $0.02 \pm 0.01$ \\
\hline & $10^{\circ} \mathrm{C}$ & $0.05 \pm 0.01$ & $0.05 \pm 0.01$ & $0.05 \pm 0.01$ & $0.04 \pm 0.01$ & $0.03 \pm 0.01$ & $0.03 \pm 0.00$ & $0.02 \pm 0.01$ \\
\hline & $0^{\circ} \mathrm{C}$ & $0.05 \pm 0.01$ & $0.05 \pm 0.01$ & $0.04 \pm 0.01$ & $0.04 \pm 0.01$ & $0.03 \pm 0.01$ & $0.03 \pm 0.01$ & $0.02 \pm 0.01$ \\
\hline \multirow{3}{*}{$\begin{array}{l}\text { Deoxy } \mathrm{Hb} \\
(\mathrm{mM})\end{array}$} & $20^{\circ} \mathrm{C}$ & $0.03 \pm 0.01$ & $0.04 \pm 0.01$ & $0.04 \pm 0.02$ & $0.05 \pm 0.02$ & $0.06 \pm 0.03$ & $0.07 \pm 0.03$ & $0.07 \pm 0.03$ \\
\hline & $10^{\circ} \mathrm{C}$ & $0.03 \pm 0.01$ & $0.04 \pm 0.01$ & $0.05 \pm 0.02$ & $0.06 \pm 0.02$ & $0.07 \pm 0.02$ & $0.08 \pm 0.03$ & $0.09 \pm 0.03$ \\
\hline & $0^{\circ} \mathrm{C}$ & $0.03 \pm 0.01$ & $0.04 \pm 0.01$ & $0.05 \pm 0.01$ & $0.05 \pm 0.02$ & $0.06 \pm 0.02$ & $0.07 \pm 0.02$ & $0.08 \pm 0.02$ \\
\hline \multirow{3}{*}{$\begin{array}{c}\text { Total Hb } \\
(\mathrm{m} \overline{\mathrm{M}})\end{array}$} & $20^{\circ} \mathrm{C}$ & $0.08 \pm 0.02$ & $0.08 \pm 0.02$ & $0.09 \pm 0.02$ & $0.09 \pm 0.02$ & $0.09 \pm 0.03$ & $0.09 \pm 0.03$ & $0.09 \pm 0.03$ \\
\hline & $10^{\circ} \mathrm{C}$ & $0.08 \pm 0.02$ & $0.09 \pm 0.02$ & $0.09 \pm 0.02$ & $0.10 \pm 0.02$ & $0.10 \pm 0.02$ & $0.10 \pm 0.03$ & $0.11 \pm 0.03$ \\
\hline & $0^{\circ} \mathrm{C}$ & $0.08 \pm 0.02$ & $0.09 \pm 0.02$ & $0.09 \pm 0.02$ & $0.09 \pm 0.02$ & $0.09 \pm 0.02$ & $0.10 \pm 0.02$ & $0.10 \pm 0.02$ \\
\hline \multirow{3}{*}{$\begin{array}{l}\mathrm{S}_{\mathrm{t}} \mathrm{O}_{2} \\
(\%)\end{array}$} & $20^{\circ} \mathrm{C}$ & $65.5 \pm 6.1$ & $57.0 \pm 10.1$ & $50.3 \pm 12.7$ & $42.7 \pm 14.3$ & $34.8 \pm 15.1$ & $29.0 \pm 14.8$ & $25.5 \pm 13.6$ \\
\hline & $10^{\circ} \mathrm{C}$ & $64.4 \pm 4.1$ & $54.5 \pm 8.2$ & $49.7 \pm 7.6$ & $43.8 \pm 8.2$ & $35.8 \pm 8.4$ & $26.0 \pm 6.8$ & $21.0 \pm 8.4$ \\
\hline & $0^{\circ} \mathrm{C}$ & $60.7 \pm 4.1$ & $53.0 \pm 5.5$ & $48.7 \pm 5.8$ & $41.2 \pm 9.4$ & $34.8 \pm 12.0$ & $29.0 \pm 12.5$ & $24.9 \pm 12.9$ \\
\hline
\end{tabular}

Oxy_Hb: oxygenated hemoglobin, Deoxy_Hb: deoxygenated hemoglobin, Total_Hb: total hemoglobin, $\mathrm{S}_{\mathrm{t}} \mathrm{O}_{2}$ : tissue oxygen saturation.

Table 5. Change of exercise performance (descriptive statistics; Mean \pm SD)

\begin{tabular}{cccc}
\hline \hline Variables & $20^{\circ} \mathrm{C}$ & $10^{\circ} \mathrm{C}$ & $0{ }^{\circ} \mathrm{C}$ \\
\hline $\mathrm{VO}_{2} \mathrm{max}(\mathrm{mL} / \mathrm{min} / \mathrm{kg})$ & $48.3 \pm 5.9$ & $46.0 \pm 5.2$ & $44.3 \pm 4.9^{\ddagger}$ \\
\hline Exercise load (Watt/kg) & $3.2 \pm 0.3$ & $3.1 \pm 0.3$ & $3.1 \pm 0.3$ \\
\hline Exercise time (min) & $16.0 \pm 2.0$ & $15.4 \pm 2.0^{\dagger}$ & $15.4 \pm 2.1^{\ddagger}$ \\
\hline \hline
\end{tabular}

$\uparrow$ : significant difference between $20^{\circ} \mathrm{C}$ and $10^{\circ} \mathrm{C}$, $\$$ : significant difference between $20^{\circ} \mathrm{C}$ and $0^{\circ} \mathrm{C} . \mathrm{VO}_{2}$ max: maximal oxygen consumption. 



Fig. 4. Change of energy metabolism parameters at rest and during exercise (Mean $\pm \mathrm{SD}$ ).

(A) Change of $\mathrm{HR}$, (B) Change of VE, (C) Change of $\mathrm{VO}_{2}$, (D) Change of $\mathrm{VCO}_{2}$. (E) Change of RER, (F) Changes of blood lactate level. *: signficant interaction, + : significant difference between $20^{\circ} \mathrm{C}$ and $0^{\circ} \mathrm{C}$ at each exercise load, $\#$ : significant difference between $10^{\circ} \mathrm{C}$ and $0^{\circ} \mathrm{C}$ at each exercise load. $\mathrm{HR}$ : heart rate, $\mathrm{VE}$ : minute ventilation, $\mathrm{VO}_{2}$ : oxygen uptake, $\mathrm{VCO}_{2}$ : cardon dioxide excretion, $\mathrm{RER}$ : respiratory exchange ratio.

보였으나(p〈.05) $75 \mathrm{watt}$ 와 $100 \mathrm{watt}$ 에서는 $10^{\circ} \mathrm{C}$ 저온 과 $0^{\circ} \mathrm{C}$ 저온 사이에서만 유의한 차이를 보였다 $(\mathrm{p}<.05)$. $\mathrm{VO}_{2}$ 는 운동 중 $50 \mathrm{watt}$ 에서 $20^{\circ} \mathrm{C}$ 상온과 $0^{\circ} \mathrm{C}$ 저온 사이 에, $75 \mathrm{watt}$ 와 $100 \mathrm{watt}$ 에서 $20^{\circ} \mathrm{C}$ 상온 및 $10^{\circ} \mathrm{C}$ 저온과 $0^{\circ} \mathrm{C}$ 저온 사이에 유의한 차이를 보였으며 $(\mathrm{p}<.05), 0^{\circ} \mathrm{C}$ 저 온에서 높은 값을 나타냈다( $\mathrm{p}<.05) . \mathrm{VCO}_{2}$ 는 안정시부터 $125 \mathrm{watt}$ 까지의 모든 시점에서 $0^{\circ} \mathrm{C}$ 저온의 경우 $20^{\circ} \mathrm{C}$ 상 온 및 $10^{\circ} \mathrm{C}$ 저온보다 유의하게 높은 값을 나타냈다 ( $p<.05)$.

\section{골격근 산소화 농도의 변화}

상온과 두 가지 저온환경에서의 안정시와 GXT 직후 골격근 산소화 농도에 해당되는 $\mathrm{Oxy}_{-} \mathrm{Hb}$, Deoxy_Hb, Total_Hb, $\mathrm{S}_{\mathrm{t}} \mathrm{O}_{2}$ 에 대한 변화는 〈Table 4〉 및 〈Figure 5〉 에서 보는 바와 같다. $\mathrm{Oxy}_{-} \mathrm{Hb}$ 를 제외한 Deoxy_Hb,
Total_Hb, $\mathrm{S}_{\mathrm{t}} \mathrm{O}_{2}$ 에서 유의한 상호작용효과가 나타났으나 사후분석결과 저온환경에 따른 특별한 차이는 나타나지 않았다.

\section{운동수행능력의 변화}

상온과 두 가지의 저온환경에서의 운동수행능력의 변 화는 〈Table 5〉 및 〈Figure 6>과 같다. $\mathrm{VO}_{2} \max$ 와 운동 지속시간에 있어서 환경에 따른 유의한 주효과 $(\mathrm{p}<.05)$ 가 나타났다. 이에 대한 사후분석 결과 $\mathrm{VO}_{2} \max$ 는 $0^{\circ} \mathrm{C}$ 저온 에서 $20^{\circ} \mathrm{C}$ 상온보다 유의하게 낮은 값 $(\mathrm{p}<.05)$ 을 나타냈 으며, 운동지속시간에서는 $10^{\circ} \mathrm{C}$ 와 $0^{\circ} \mathrm{C}$ 저온에서 $20^{\circ} \mathrm{C}$ 상 온보다 유의하게 낮은 값(p<.05)을 보였다. 

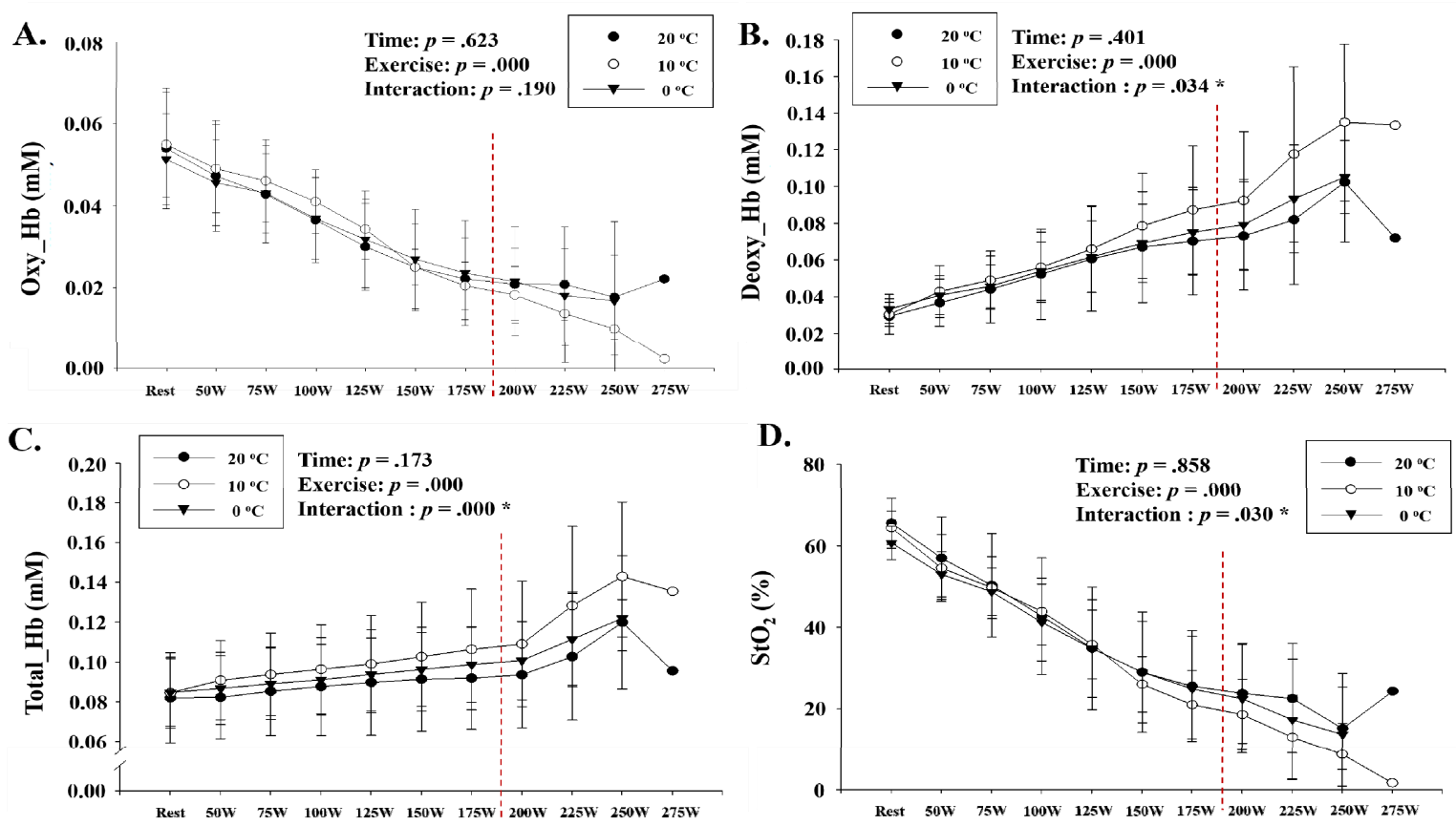

Fig. 5. Change of skeletal muscle oxygen profiles at rest and during exercise (Mean $\pm \mathrm{SD}$ ).

(A) Change of Oxy_Hb, (B) Change of Deoxy_Hb, (C) Change of Total_Hb, (D) Change of $\mathrm{S}_{\mathrm{t}} \mathrm{O}_{2}$. * : signficant interaction, Oxy_Hb: oxygenated hemoglobin, Deoxy_Hb: deoxygenated hemoglobin, Total_Hb: total hemoglobin, $\mathrm{S}_{\mathrm{t}} \mathrm{O}_{2}$ : tissue oxygen saturation.


Fig. 6. Change of exercise performance (Mean $\pm \mathrm{SD}$ ).

(A) change of $\mathrm{VO}_{2} \max$, (B) change of maximal exercise load, (C) change of exercise time to exhaustion. *: signficant main effect within environment, $\uparrow$ : significant difference between $20^{\circ} \mathrm{C}$ and $10^{\circ} \mathrm{C}$, $\$$ : significant difference between $20^{\circ} \mathrm{C}$ and $0^{\circ} \mathrm{C}$. $\mathrm{VO}_{2}$ max: maximal oxygen consumption. 


\section{논의}

일반적으로 저온환경(cold stress)에서의 급성노출 (acute exposure)은 인체의 운동 시 속도 및 힘을 저하시 키고 생리적 반응에 영향을 미쳐 운동수행능력을 제한하 는 것으로 보고되고 있다(Son'kin et al., 2014; Wakabayashi et al., 2015). 특히 운동 시 저온환경의 급성노출에 의해 초래되는 골격근 성능의 감소는 부분적 으로 신경전도 속도 둔화에 의해 기인하게 되며 (Wakabayashi et al., 2015), 추가적으로 근육수축 속 도의 감소는 ATP 이용률 저하, SR에서의 느린 칼슘이온 방출 및 흡수에 영향을 받는다(Edwards et al., 1972; Herve et al., 1992; He et al., 2000). 이렇듯 저온환경 의 급성노출에 의한 운동수행능력의 감소는 신경근 기능 (neuromuscular function)과 근육대사(muscle metabolism)에 의한 잠재적 기전에 의해 주로 영향을 받 는 것으로 보고되고 있다.

두 가지 잠재적 기전 중 신경근 기능과 관련하여 Petrofsky \& Laymon(2005)와 Drinkwater \& Behm(2007)는 저온 환경에의 노출이 근전도(electromyography, $\mathrm{EMG}$ )의 진폭을 감소시키며, 이러한 $\mathrm{EMG}$ 진폭의 감소는 피부표 면에 있는 근섬유의 낮은 활성도를 반영한다고 설명하였 고 이에 운동수행능력이 감소한다고 보고하였다. 근육대 사와 관련하여, 여러 선행연구에서 저온환경에서의 급성 노출이 심혈관계에서 근조직으로의 혈류 제한에 의해 산 소공급을 감소시키고 이에 운동수행능력을 저하시킨다 고 보고되고 있다(Rennie et al., 1980; Thorsson et al., 1985). 특히 저온환경과 근육대사의 관계에 대해 보 다 정확하게 연구를 수행하기 위해서는 NIRS를 활용하 는 것이 필수적이다. 본 연구에서와 같이 환경제어챔버를 이용한 전신의 저온환경 노출 관련 연구는 아니지만 이와 관련하여 Yanagisawa et al. (2007)은 NIRS를 활용하 여 피부표면에서 저온환경에 의해 냉각된 발목등축근 (ankle dorsiflexor muscle)에서 안정시 Total_Hb이 유 의하게 감소하였다고 보고하였으며, Hom et al.(2004) 또한 아이스 백을 이용하여 1시간 동안 발목등축근 (ankle dorsiflexor muscle)을 냉각시킨 후 안정시 근육 에서의 산소포화도와 Total_Hb이 유의하게 감소하였다 고 보고하였다.
이러한 선행연구를 바탕으로 하여, 본 연구에서는 20 대의 건강한 남성을 대상으로 상온환경 $\left(20^{\circ} \mathrm{C}\right)$ 과 비교하 여 다양한 저온환경 $\left(10^{\circ} \mathrm{C}, 0^{\circ} \mathrm{C}\right)$ 에서의 급성노출이 운동 수행능력과 운동 중 생리적 반응에 미치는 영향을 호흡가 스를 통한 에너지 대사와 NIRS를 활용한 골격근 산소화 농도를 통해 검토하고자 하였다. 그 결과 저온환경은 동 일강도의 운동 시 체온의 감소와 $\mathrm{VE}, \mathrm{VO}_{2}, \mathrm{VCO}_{2}$ 의 증가 를 가져오고 이러한 생리적 변화로 인해 운동수행능력을 감소시킨다는 것을 확인할 수 있었으며, 특히 이러한 현 상은 $20^{\circ} \mathrm{C}$ 상온과 비교했을 때 $10^{\circ} \mathrm{C}$ 저온환경 보다 $0^{\circ} \mathrm{C}$ 저온환경에서 두드러지게 나타남을 확인할 수 있었다.

본 연구의 결과를 대사 및 실혐관계 측면에서 선행연 구의 결과와 비교했을 때, 저온환경에서의 급성노출은 인 체에 스트레스로 작용하여 교감신경계 활성도 증가와 부 교감신경계 활성도 감소를 가져오고 이에 생리적으로 말 초혈관의 저항을 증가시켜 $\mathrm{HR}$ 과 $\mathrm{BP}$ 를 높이게 되며, 결 과적으로 최대하 운동 중 심혈관계 기능을 감소시키고 대 사기능의 저하를 나타내게 되는 것으로 보고되고 있다 (Gonzalez-Camarena et al., 2000; Nybo et al., 2001). 특히 저온환경에 의해 냉각된 근조직으로의 혈류 제한 현상은 결과적으로 산소공급을 감소시키며 근 글리 코겐의 파괴와 해당작용 촉진 현상을 나타내게 되며, 이 로 인해 혈중젖산농도가 증가되어 무산소성 역치 (anaerobic threshold)와 $\mathrm{VO}_{2} \max$ 를 감소시키고 최대 하 운동 시 에너지 대사 효율이 저하되어 결과적으로 운 동수행능력을 감소시키게 된다고 보고하고 있다(Stocks et al., 2004). 본 연구에서도 전술한 선행연구와 같이 아 마도 저온환경에의 급성노출에 의한 냉각된 근조직으로 의 혈류제한에 의해 산소공급이 감소하고 이에 동일부하 에서의 상대적 운동강도가 높아져 무산소성 대사에 더욱 의존한 결과, 동일부하에서의 $\mathrm{VE}, \mathrm{VO}_{2}, \mathrm{VCO}_{2}$ 가 저온환 경 $\left(10^{\circ} \mathrm{C}, 0^{\circ} \mathrm{C}\right)$ 에서 상온환경 $\left(20^{\circ} \mathrm{C}\right)$ 보다 유의하게 더 높 은 값을 나타낸 것으로 확인되어진다. 그리고 이러한 결 과는 본 연구와 가장 비슷한 연구설계로 9 명의 측구선수 를 대상으로 cross-over study를 바탕으로 동일한 습도 조건 $(60 \pm 10 \%)$ 에서 저온인 $10 \pm 1^{\circ} \mathrm{C}$ 과 상온인 $22 \pm 1^{\circ} \mathrm{C}$ 에 서 운동수행능력과 생리적 반응 변화를 검토한 No \& $\operatorname{Kwak}(2016)$ 의 결과와 일치한다. 물론 본 연구에서는 No \& Kwak(2016)의 연구와는 다르게 대사와 심혈관계 
측면에 있어서 $20^{\circ} \mathrm{C}$ 의 상온환경과 $10^{\circ} \mathrm{C}$ 저온환경 사이에 유의한 차이가 나타나지 않았는데 이는 상온환경에 대한 설정온도 차이 $\left(20^{\circ} \mathrm{C}\right.$ vs $\left.22^{\circ} \mathrm{C}\right)$ 및 운동프로토콜의 차이에 의한 결과로 사료되어진다.

그러나 본 연구에서 NIRS를 활용하여 안정시 및 운동 시 외측광근(Latissimus lateral muscle)의 골격근 산소 화 농도를 검토한 결과 관련 변인인 $\mathrm{Oxy}_{-} \mathrm{Hb}$, Deoxy_Hb, Total_Hb, $\mathrm{S}_{\mathrm{t}} \mathrm{O}_{2}$ 에서는 상온환경 $\left(20^{\circ} \mathrm{C}\right)$ 과 두 가지 저온환경 $\left(10^{\circ} \mathrm{C}, 0^{\circ} \mathrm{C}\right)$ 사이에 유의한 차이가 나타 나지 않았다. 이러한 선행연구와 상이한 연구결과는 아마 도 Hom et al.(2004) 및 Yanagisawa et al.(2007)은 아이스백을 이용하여 근조직을 냉각시킨 후 NIRS를 이 용하여 안정시 골격근 산소화 농도를 검토한 반면에 본 연구에서는 환경제어챔버를 이용하여 동일한 습도조건 에서 상온환경 $\left(20^{\circ} \mathrm{C}\right)$ 과 다양한 저온환경 $\left(10^{\circ} \mathrm{C}, 0^{\circ} \mathrm{C}\right)$ 에 서 최대운동 시 동일부하에서의 골격근 산소화 농도의 차 이를 검토한 결과로 사료되어진다. 본 연구와 같은 설계 로 동일부하의 운동시 골격근 산소화 농도 차이를 검토한 선행연구가 없다는 것을 고려했을 때 이에 대해서는 추가 적인 연구를 통해 저온환경이 근조직에서의 산소이용과 관련된 정확한 생리적 반응을 검토하는 것이 중요하다고 판단된다.

마지막으로 운동수행능력 측면에서 상온환경 $\left(20^{\circ} \mathrm{C}\right)$ 과 다양한 저온환경 $\left(10^{\circ} \mathrm{C}, 0^{\circ} \mathrm{C}\right)$ 을 비교했을 때, 저온환 경에서 더 낮은 $\mathrm{VO}_{2} \max$ 와 운동지속시간을 나타냈으며, 이는 전술한 바와 같이 결과적으로 혈류공급의 제한에 의 해 동일부하에서의 상대적 운동강도가 높아져 무산소성 대사에 의한 에너지 생산 의존도가 증가된 결과로 판단된 다(Stocks et al., 2004). 그러나 $20^{\circ} \mathrm{C}$ 상온환경과 $10^{\circ} \mathrm{C}$ 저온환경 간의 운동 중 대사 및 호흡순환계 변인뿐만 아 니라 NIRS 데이터에 있어서도 통계적인 유의한 차이가 없다는 점을 고려했을 때 두 환경 간 운동수행능력의 차 이를 유발하는 요인을 다양한 생리적·생화학적 측면에서 검토하는 것은 매우 중요하다고 사료된다.

\section{결론 및 제언}

본 연구는 10 명의 건강한 20 대 남자대학생을 대상으
로 상온환경 $\left(20^{\circ} \mathrm{C}\right)$ 과 비교하여 다양한 저온환경 $\left(10^{\circ} \mathrm{C}\right.$, $\left.0^{\circ} \mathrm{C}\right)$ 에서의 급성노출이 체온, 호흡가스를 통한 에너지 대사, 골격근 산소화 농도 및 운동수행능력에 미치는 영 향을 검토하기 위하여 수행되었다. 그 결과 각 두 가지의 저온환경 $\left(10^{\circ} \mathrm{C}, 0^{\circ} \mathrm{C}\right)$ 은 상온환경 $\left(20^{\circ} \mathrm{C}\right)$ 에 비해 동일강 도의 운동 시 체온의 감소와 $\mathrm{VE}, \mathrm{VO}_{2}, \mathrm{VCO}_{2}$ 의 증가와 같은 대사적 측면의 생리적 변화를 통해 운동수행능력을 감소시키는 것을 확인할 수 있었으며, 이러한 현상은 2 $0^{\circ} \mathrm{C}$ 상온과 비교했을 때 $10^{\circ} \mathrm{C}$ 저온환경 보다 $0^{\circ} \mathrm{C}$ 저온환 경에서 두드러지게 나타남을 확인할 수 있었다.

이에 추후 엘리트 선수를 대상으로 저온환경에서의 급 성노출이 운동수행능력과 NIRS를 포함한 다양한 생리적 반응에 미치는 영향을 검토하여 저온환경에서의 경기 및 시합에 대비하기 위한 기초자료로 활용하고 저온환경에 서도 최상의 경기력을 유지할 수 있는 다양한 스포츠 제 품뿐만 아니라 영양, 운동 트레이닝, 컨디셔닝 전략들을 개발해야 할 것이다.

\section{참고문헌}

Binzoni, T., Ngo, L., Hiltbrand, E., Springett, R., \& Delpy, D. (2002). Non-standard $\mathrm{O}_{2}$ consumption - temperature curves during rest and isometric exercise in human skeletal muscle. Comparative Biochemistry and Physiology Part A: Molecular \& Integrative Physiology, 132(1), 27-32.

Castellani, J. W., \& Young, A. J. (2016). Human physiological responses to cold exposure: Acute responses and acclimatization to prolonged exposure. Autonomic Neuroscience, 196, 63-74.

González-Camarena, R. A. M. O. N., Carrasco-Sosa, S. A. L. V. A. D. O. R., Román-Ramos, R. U. B. É. N., Gaitán-González, M. J., Medina-Bañuelos, V. E. R. Ó. N. I. C. A., \& Azpiroz-Leehan, J. O. A. Q. U. Í. N. (2000). Effect of static and dynamic exercise on heart rate and blood pressure variabilities. Medicine and Science in Sports and Exercise, 32(10), 1719-1728.

De Jong RH, Hershey WN and Wagman IH. 1966. Nerve conduction velocity during hypothermia in man. Anesthesiology 27: 805-810.

Drinkwater, E. J., \& Behm, D. G. (2007). Effects of $22^{\circ} \mathrm{C}$ muscle 
temperature on voluntary and evoked muscle properties during and after high-intensity exercise. Applied Physiology, Nutrition, and Metabolism, 32(6), 1043-1051.

Drinkwater, E. (2008). Effects of peripheral cooling on characteristics of local muscle. Medicine and Sports Science, 53, 74-88.

Edwards, R. H. T., Harris, R. C., Hultman, E., Kaijser, L., Koh, D., \& Nordesjö, L. O. (1972). Effect of temperature on muscle energy metabolism and endurance during successive isometric contractions, sustained to fatigue, of the quadriceps muscle in man. The Journal of Physiology, 220(2), 335-352.

Falk, B., Bar-Or, O., Smolander, J., \& Frost, G. (1994). Response to rest and exercise of the cold: effects of age and aerobic fitness. Journal of Applied Physiology, 76(1), 72-78.

Gregson, W., Black, M. A., Jones, H., Milson, J., Morton, J., Dawson, B., Atkinson, G., \& Green, D. J. (2011). Influence of cold water immersion on limb and cutaneous blood flow at rest. The American Journal of Sports Medicine, 39(6), 1316-1323.

He, Z. H., Bottinelli, R., Pellegrino, M. A., Ferenczi, M. A., \& Reggiani, C. (2000). ATP consumption and efficiency of human single muscle fibers with different myosin isoform composition. Biophysical Journal, 79(2), 945-961.

Herve, J. C., Yamaoka, K., Twist, V. W., Powell, T., Ellory, J. C., \& Wang, L. C. (1992). Temperature dependence of electrophysiological properties of guinea pig and ground squirrel myocytes. American Journal of Physiology-Regulatory, Integrative and Comparative Physiology, 263(1), R177-R184.

Hom, C., Vasquez, P., \& Pozos, R. S. (2004). Peripheral skin temperature effects on muscle oxygen levels. Journal of Thermal Biology, 29(7-8), 785-789.

Lee, S. B. \& Jeon, Y. K. (2013). The effects of exercise performance ability changes in external environmental temperature. The Journal of Korea Society for Wellness, 8(1), 151-159.

Manou-Stathopoulou, V., Goodwin, C. D., Patterson, T., Redwood, S. R., Marber, M. S., \& Williams, R. P. (2015). The effects of cold and exercise on the cardiovascular system. Heart, 101(10), 808-820.

No, M., Kwak H. B. Effects of environmental temperature on physiological response during submaximal and maximal exercise in soccer players. Integrative Medicine Research, 5(3), 216-222.

Nybo, L., \& Nielsen, B. (2001). Hyperthermia and central fatigue during prolonged exercise in humans. Journal of Applied Physiology, 91(3), 1055-1060.

Oksa, J. (2002). Neuromuscular performance limitations in cold. International Journal of Circumpolar Health, 61(2), 154-162.

Petrofsky, J., \& Laymon, M. (2005). Muscle temperature and EMG amplitude and frequency during isometric exercise. Aviation, Space, and Environmental Medicine, 76(11), 1024-1030.

Pilcher, J. J., Nadler, E., \& Busch, C. (2002). Effects of hot and cold temperature exposure on performance: a meta-analytic review. Ergonomics, 45(10), 682-698.

Racinais, S., \& Oksa, J. (2010). Temperature and neuromuscular function. Scandinavian Journal of Medicine \& Science in Sports, 20, 1-18.

Rennie D, Park Y, Veicsteinas A and Pendergast D. (1980). Metabolic and circulatory adaptation to cold water stress. Exercise Bioenergetics and Gas Exchange, 315-321, Elsevier/North-Holland Biomedical Press, Amsterdam.

Son'kin, V. D., Yakushkin, A. V., Akimov, E. B., Andreev, R. S., Kalenov, Y. N., \& Kozlov, A. V. (2014). The physiological analysis of cross adaptation to regular cold exposure and physical activities. Human Physiology, 40(6), 669-682.

Stocks, J. M., Taylor, N. A., Tipton, M. J., \& Greenleaf, J. E. (2004). Human physiological responses to cold exposure. Aviation, Space, \& Environmental Medicine, 75(5), 444-457.

Thorsson, O., Lilja, B., Ahlgren, L. A. R. S., Hemdal, B., \& Westlin, N. I. L. S. (1985). The effect of local cold application on intramuscular blood flow at rest and after running. Medicine and Science in Sports and Exercise, 17(6), 710-713.

Wakabayashi, H., Oksa, J., \& Tipton, M. J. (2015). Exercise performance of acute and chronic cold exposure. The Journal of Physical Fitness \& Sports Medicine, 4(2), 177-185.

Yanagisawa, O., Homma, T., Okuwaki, T., Shimao, D., \& Takahashi, H. (2007). Effects of cooling on human skin and skeletal muscle. European Journal of Applied Physiology, 100(6), 737-745. 


\title{
저온환경에의 급성노출이 에너지 대사, 골격근 산소화 농도 및 운동수행능력에 미치는 영향
}

\author{
박훈영 ${ }^{1}$, 정원상 ${ }^{2}$, 황혜정 ${ }^{2}$, 김성우 ${ }^{3}$, 정경화 $^{4}$, 박예람 ${ }^{4}$, 황든솔 ${ }^{4}$, \\ 견성환 $^{4}$, 서종범 ${ }^{4}$, 하유진 ${ }^{4}$, 장인권 ${ }^{4}$, 김지수 ${ }^{5}$, 임기원 $^{6}$ \\ 1건국대학교 부교수 \\ 2건국대학교 학술연구교수 \\ 3건국대학교 전임연구원 \\ 4건국대학교 연구원 \\ 5 건국대학교 조교수 \\ 6 건국대학교 교수
}

〔목적〕 본 연구는 20 대 남자대학생을 대상으로 상온환경 $\left(20^{\circ} \mathrm{C}\right)$ 과 비교하여 다양한 저온환경 $\left(10^{\circ} \mathrm{C}, 0^{\circ} \mathrm{C}\right)$ 에의 급성노출이 운동수행능력과 운동 중 생리적 반응에 미치는 영향을 호흡가스를 통한 에너지 대사와 NIRS 를 활용한 골격근 산소화 농도를 통해 검토하고자 수행되었다. 〔방법〕 본 연구의 목적을 달성하기 위해 총 10 명의 건강한 20 대 남자대학생을 선별하였으며, 이를 대상으로 각 환경조건 $\left(20^{\circ} \mathrm{C}, 10^{\circ} \mathrm{C}, 0^{\circ} \mathrm{C}\right)$ 에서 각각 30 분간 안정상태를 유지한 후 종속변인(체온, 호흡가스를 통한 에너지 대사, 골격근 산소화 농도, 운동수행능력) 에 대한 안정시 및 최대운동부하 검사 중 측정을 실시하였다. 각 환경조건에서의 GXT 검사 간 일주일 간격을 두었으며, 환경조건에 대한 순서를 불규칙하게 무작위로 선정하였다. 〔결과〕 체온의 경우, 각 기온 조건에서 운동 직후 $10^{\circ} \mathrm{C}$ 저온과 $0^{\circ} \mathrm{C}$ 저온에서 체온의 유의한 감소가 나타났으며 $(\mathrm{p}<.05)$, 안정시와 운동 직후 각각에 서의 기온에 따른 차이에서는 양쪽 모두에서 기온이 감소함에 따라 그에 비례하여 체온이 유의하게 감소하였 다( $\mathrm{p}<.05)$. 에너지 대사 관련 변인의 경우, 심박수와 혈중젖산농도는 어떠한 차이도 나타나지 않았으며, 호흡 교환율은 안정시에 $0{ }^{\circ} \mathrm{C}$ 저온에서 $20^{\circ} \mathrm{C}$ 상온 보다 유의하게 높은 값 $(\mathrm{p}<.05)$ 을 나타났다. 분당환기량, 산소섭 취량, 이산소탄소배출량은 여러 시점에서 $20^{\circ} \mathrm{C}$ 상온 및 $10^{\circ} \mathrm{C}$ 저온과 비교했을 때 $0^{\circ} \mathrm{C}$ 저온에서 유의하게 낮은 값를 보였다(p<.05). 골격근 산소화 농도는 모든 변인에 있어서 저온환경에 따른 안정시 및 운동 중 특별한 변화가 나타나지 않았다. 운동수행능력의 경우, 최대산소섭취량은 $0^{\circ} \mathrm{C}$ 저온에서 $20^{\circ} \mathrm{C}$ 상온보다 유의하게 낮 은 값을 나타냈으며 $(\mathrm{p}<.05)$, 운동지속시간 또한 $0^{\circ} \mathrm{C}$ 저온과 $10^{\circ} \mathrm{C}$ 저온에서 $20^{\circ} \mathrm{C}$ 상온보다 유의하게 낮은 값 을 보였다( $\mathrm{p}$ 〈.05). 〔결론〕 본 연구의 결과를 통해 저온환경은 동일강도의 운동 시 체온의 감소와 분당환기량, 산소섭취량, 이산화탄소 배출량의 증가를 가져오고 이러한 생리적 변화로 인해 운동수행능력을 감소시킨다. 그리고 이러한 현상은 $20^{\circ} \mathrm{C}$ 상온과 비교했을 때 $10^{\circ} \mathrm{C}$ 저온환경 보다 $0^{\circ} \mathrm{C}$ 저온환경에서 두드러지게 나타남을 확인할 수 있었다.

주요어: 저온환경, 에너지 대사, 골격근 산소화 농도, 운동수행능력 